\title{
The Burden of the Female Body: An Islamic Feminist Reading of Qaisra Shahraz's Typhoon
}

\author{
NAUSHEEN ISHAQUE ${ }^{1}$
}

\begin{abstract}
A sequel to The Holy Woman(2001), Typhoon(2003) is Qaisra Shahraz's second novel. This paper analyses how Shahraz continues problematizing female sexuality and the politics attached to it, especially in rural Pakistan. It dilates upon the discourse that surrounds the female body and sexuality in Pakistan society within and outside the framework of marriage. What is at stake is that women's own sexuality becomes a burden for them. On the contrary, men take pride in their masculinity which gives authenticity to their voice. The cultural colonization of women's lives (as it appears in Shahraz's novel) is addressed under the theoretical rationale of Islamic feminism. This is done with the aim to locate the space granted to women in Islam, especiallywhen it comes to the female body and its sexuality.
\end{abstract}

Keywords: female body;burden; shame; Islamic feminism; kacheri;fitna;divorce

Qaisra Shahraz's (b. 1958) worldview and experience as an author is enriched by two cultures: Pakistan and England. Being a diasporic writer, however, Pakistan has never been away from Shahraz's imagination. Shahraz's literary sensibility is overtly social (Siddiqui 2011: 197) and focuses exclusively on the woman question, especially as it stands out in the postcolonial society of rural Pakistan (Ishaque 2017: 1). Shahraz's novels, especially The Holy Woman (2001) and Typhoon (2003), foreground problems related to female identity and space against the regional and tribal backdrop of Pakistan. She almost redefines feminism when it comes to her fiction set in Pakistan. As a writer, she wishes to introduce the Muslim world to the Western readers. Thus, Shahraz "is one writer who has made the Muslim voice heard" (Hasan 2016: 172), while it is important to see "her role in debunking the myths surrounding Muslim women" (ibid). This, and much more, she shares in one of her interviews that published in Jakarta Post (https://www.thejakartapost.com/news/2008/01/31/qaisra-shahraz-unveiling-muslimwomen.html) :

One of my aims in writing The Holy Woman was to introduce the Muslim world. I was writing it when Salman Rushdie came out with The Satanic Verses. I was very angry ... I am a writer and I love literature ... so what I wanted to do with my book was open the Muslim world out and show the positive side.

This is further strengthened by her views on the situation of Muslim women and her own feminist vision:

I always felt strongly about women's lives, because I'm always comparing my life to other women's lives, and I think I'm so lucky because I live in the West, I have an education, I have a career and opportunity and I want other women to have the same. I am not a Western feminist; (I am) a feminist within a Muslim framework.

\footnotetext{
${ }^{1}$ Nausheen Ishaque, Ph. D. Assistant Professor, Department of English Language and Literature The University of Lahore. 1- Km Raiwind Rd, Sultan Town, Lahore, PUNJAB, Pakistan. Email: nausheen.ishaque@ell.uol.edu.pk
} 
Shahraz emphasizes on distinguishing the cultural from the religious. Her account of the cultural practices/notions of haqbakhshwana in The Holy Woman, karokari in Typhoon and perchanvah in Revolt (2013)can arguably "be used by those withvested interests to entrench cultural caricaturing and stereotyping of Islam, Muslims andPakistan" (Hasan 2016: 176). For readers' understanding, it is imperative to explain the notions of haqbakhshwana, karo kari and perchanvah. Haqbakhshawana is a cultural tradition, coming specially from rural Sindh in Pakistan, that makes girls give up on their right of inheritance in property and pushes them into a life of celibacy by having them get married to the Qur'an. As for karo kari, the word literally means 'black male' (karo) and 'black female' (kari) in Sindhi language. It is a form of honor killing meant to restore the reputation of the family. Finally, perchanvah is the superstitious belief that an evil shadow (of a person or supernatural being) can cause harm to people.

Shahraz, nevertheless, is against caricaturing or stereotyping people, practices and ethnicities, especially when done for creating sensationalism (ibid). As for her narrative plots that are knit around the above-mentioned cultural practices, Sharhraz clarifies her take on these to her readers: "I make it very clear that the cultural practices I have discussed have nothing to do with Islam. So there is no stereotyping of Islam, so to speak, in my work" (Hasan 2016: 177).

In Shahraz's fictional world, women confront situations that display an obvious schism between the cultural and the religious.How the former is justified in the garb of the latter is the actual adversity featuring her narratives. This naturally brings in the woman question wherein Shahraz negotiates the space given to women in Islam. Tragedy, in Shahraz's plots, occurs when the dangerous chemistry between culture, and the abuse of religion take place. What one essentially learns from Shahraz's feminist vision is the recodification of the dominant practices (like veiling and many others) in favor of Muslim women.

Shahraz's women bear the burden of their own sexuality and the honor attached to it as shown in her Typhoon. Interestingly, it is men who pose threat to women's honor and, ironically, againit is men who restore women's chastity in the society. In an international context, Shahraz embarks on the issues of female identity and reconfiguration of the ritual which makes her stand apart from her contemporaries, especially in Pakistani anglophone literary tradition. Her take on female space essentially imparts consciousness to the readers on the necessity to mobilize female Muslim strength from all across the world,and reconfigure it (in their interest) globally and transculturally (Kidwai 2011: 85).

\section{The Theoretical Paradigm of Islamic Feminism}

The theoretical underpinning of this paper has been done by deploying the theoretical rationales of postcolonial feminism and Islamic feminism. Tracing the genealogy of these two conceptual strand calls for volumes, though it is suffice to mention here that Islamic feminism is a recent development in the larger theoretical domain of postcolonial feminism. For Young (2003: 116):

Postcolonial feminism is certainly concerned to analyze the nervous conditions of being a woman in a postcolonial environment, whether in the social oppression of the post colony or metropolis. Its concern is not in the first place with individual problems but with those that affect the whole communities.

As for Islamic feminism, Margot Badran (2009) discusses its episteme in terms of its being a combination of activist and intellectual work carried out in diverse parts of the world. Islamic feminism is self-containing as it addresses the diversity of culture and negotiates multiplicity of identity which features the lives of Muslims across the globe today. Like several other sociopolitical and cultural ideologies, both postcolonial feminism and Islamic feminism have also penetrated the corpus of literature, something arguably beneficial in shaping the rationale and relevance of the third world literature to today's most kaleidoscopic world order.

The Islamic feminist approach towards studying literary works also calls for adopting principles of practical theology. Although popularly known to be associated with the academic 
study of Christianity, practical theology should inspire research in Islamic studies too (Isgandarova 2014). For Cowan (2000: 123):

[T]he hallmark of "practical theology" is the insistence that the point of theological interpretation is not simply to contemplate or comprehend the world as it is, but to contribute to the world's becoming what God intends that it should be, as those intentions have been interpreted by the great theistic traditions.

In the same way, Smith (2008: 204) holds that:

The key characteristic of practical theology is that it seeks to apply theological reflection to solve real-life problems. Its point of departure is a problem in the real world, that is, a real-life situation that is not as it should be. By means of a rigorous analysis of the problem, its causes and possible solutions, the researcher seeks to transform the situation.

The hermeneutics of practical theology are helpful in interpreting both our world and our traditions, thus facilitating the conception of the 'lived religion' by addressing religion as a cultural reality.

\section{The Politics of Shame and the Female Body}

Taking some of the characters from The Holy Woman, the main plot of Typhoon features new characters like Gulshan and Haroon, who are married and have a son, and Naghmana, Harron's first wife who he married while they both were students. Shahraz has masterfully divided the plot into four parts - both spatially and temporally. In the first part, as the novel opens, we see Gulshan. She is a middle-aged woman who travels to the village of Chiragpur - a village in Sindh, Pakistan. The readers are transported twenty years back in time, asGulshan broods over her life in the same village with her husband Haroon and a young son. The story reaches its climax in the next two parts which hinge upon the alleged adultery of Naghmana and Haroon.

A typhoon enters the village of Chiragpur with the advent of Naghmana - a young and modern city woman. She is on a visit to her aunt Fatima in the village where she finds Haroon. Haroon had been Naghmana's class fellow at university whom she secretly married but got separated soon. Haroon's wife Gulshan finds her world upside down when one night she discovers Haroon meeting Naghmana secretly. Gulshan's mother Hajrah feels badly betrayed at this and vows to shatter the lives of the two adulterers. The matter is taken to Siraj Din, the village elder, who calls a kacheri. Kacheri is an open court held in the countryside in the South Asian region. It is commonly headed by a senior villager - for the most part an elderly person - who is considered sagacious among the village residents. Matters of significance are brought to kacheri and decided in the presence of witnesses, victim(s) and the accused. The kacheri meetings are generally attended by a large number of people, while the verdict of the kacheri head is commonly accepted.

It is revealed by Haroon in kacheri that Naghmana is his wife whom he had married before Gulshan. This leads to a situation in which Naghmana is forced to be divorced from Haroon. Shortly after this, Naghmana leaves the village. Siraj Din and other village participants later realize they acted in haste and so, collectively suffer from a sense of guilt.

Twenty years later, Siraj Din in his death bed wishes to have Naghmana forgiven him. On Siraj Din's pleas, Naghmana comes back to Chiragpur with her second husband Jahangir and their two children. She revisits her past and reveals her shameful secret to Jahangir who is unable to accept her past. So, he goes back to the city taking both his kids along without Naghmana. Naghmana, all frustrated and unable to cope with the situation this time, commits suicide by drowning herself in the village well.

In the course of the novel, Shahraz questions the status of the female body. Hajrah, Gulshan's mother, confronts Haroon in extreme anger as she snarls, "What does this slut have that my daughter doesn't? Gulshan is intact in all parts, isn't she?" (Typhoon 2003: 48). Thus, Naghmana's 
and Gulshan's bodies become sites of contest and scrutiny. Gulshan is deemed to lack what Naghamana can offer. Gulshan's body is presumed to be lacking, insufficient and incapable of satisfying her husband, while Naghmana is considered a "slut" and accused of leading Haroon astray because of her alluring and beautiful body. For both the women, their bodies become a burden as Naghmana is exposed to intense shame and guilt, whereas Gulshan considers her body lacking:

Is that urban woman with her short sleeved dress and loose hair more attractive? I am just a naïve desi, a simple village woman, who doesn't even know what lipstick suits her complexion. I have failed both as a woman and as a wife. I couldn't even hold onto him in my bed (Typhoon 2003: 32).

Chaudhary (2013) discusses the sense of shame which is inevitably attached to the bodies of the female characters in Shahraz's novel. To her, shame is a recurrent motif in the novel and the readers experience an interesting interplay of various forms in which shame penetrates the overall structure of the story. The lives of women in Typhoon are shrouded by a sense of intense shame which colonizes their minds and souls. Naghmana is ashamed of her alleged adultery and then faces public shaming forbeing called a whore. Ironically, this shame is brought on Naghmana by another woman, and not a man. Gulshan feels ashamed of her body which, to her, is not as alluring as that of Naghmana. Furthermore, Chaudharani Kaneez is tormented by the fact that she was raped in her early teens, which makes her husband reject her. Though she did not spend enough time with her husband (who died soon after their marriage), the little time they had spent together invariably reminds Kaneez of her ashamed body. Minor characters like Naimat Bibi and Kulsoom - the village cook and match-maker respectively - also suffer a sense of shame and guilt for spreading wrong news of Naghmana's adultery with Haroon (since later it is revealed that they were actually married). Similarly, the thirty-seven-year-old Jamila is ashamed of her unwanted pregnancy.

For Lindo (2013: 212), shame is a feeling which is necessarily characterized by bodily awareness besides visual and verbal imaging of the psychic. As a result of this, shame exposes the instinctual which is intrinsic to all human experiences. The fact that the most shame-inducing moments are those in which body loses control of itself is what reveals the relation between shame and body. Therefore, "[c]ontrolling the body's relationship with the outside world is polarized around the ability to demonstrate, in large part, a sense of shame so as to remain within the sociocultural edicts that govern its conduct".

Shame, it may be inferred, is likely to be associated with concealment. Moreover, it stands in relation with the body, especially in terms of its instinctual drives. A sense of shame emanates once the body loses control of itself - a behaviour which is antagonistic to the outside world. Shame is thus a feeling which, to a large extent, is also society-driven. This is what happens in the case of Naghmana's alleged adultery with Haroon which makes the bodies of both Gulshan and Naghmana reasons for blame and indignity in the eyes of society. One, therefore, sees Gulshan torturing herself for what is done by her husband. Haroon's infidelity is a social shame for her,since it establishes her inadequacy as a wife. A sense of low self-esteem develops within her and she curses her village-bred body in contrast to fashionable Naghmana. At this point, the discourse on rural versus urban etiquette comes in, though it is beyond the subject of this discussion. Gulshan thus punishes her body which is now loathsome for her:

Leaning against the door, she pushed her wrist into her mouth - biting on the soft flesh. The primitive animal sound was suffocated. Feeling the pain, she pulled her wrist from her mouth and looked down at her dark teeth marks (Typhoon 2003: 21).

In a patriarchal society of sexual double standards, it is the woman who has to bear the responsibility of her husband's infidelity. Gulshan brings shame on herself since she has not been able to hold her husband onto their bed; hence, Haroon steals away into the arms of another woman. Gulshan's body is, therefore, considered inferior and responsible for the wrongs of her 
husband. It becomes a site of failure and shame as she is unsuccessful in satisfying what a man wants from his wife.

At this point, it is imperative to see how Islam looks at female sexuality especially within marriage. Islam contains a positive view of human sexuality. Both classical and contemporary scholarship among Muslims recognizes sexual need and appetite on the part of a woman. However, there remains a difference between the classical scholars and the modern ones as the former focus more on the discord-producing results of female sexual discontentment which may potentially lead to fitna. According to Leo (2005: 135), fitna is a word with various connotations: chaos and disorder, female desirability, female power, male weakness, etc. In the current context, fitna is a concept owing to the supposed unregulated sexual desires on women's part and the problematic desires that may come among men. Ironically, however, there has been an increasing emphasis on wives' obligation to be sexually available to their husbands (Ali 2008). The contemporary scholars, nonetheless, go more for women's sexual rights with reference to marriage. They lay greater stress on female pleasure and orgasm in isolation from reproduction. Moosa (2005) mentions Al-Ghazali who has drawn on significant sources from the Qur'an and hadith with reference to gratification among females in the sexual act. According to the oft-cited writings by al-Ghazali, it is the responsibility of men to make their wives' sexual experiences pleasurable. Moosa (2005) in Al-Ghazali and the Poetics of Imagination refers to Ghazali's discussion on sex in Ihya as a primary point of reference for scholars on sexuality in classical Muslim tradition.

Muslim authorities have,nevertheless, focused more on the fulfilment of male sexual desire within the context of marriage. Classical Muslim scholarship draws on several hadithswhich delineate dire consequences for the women who refuse the sexual overtures of their husbands. The classical Muslim discourse on sex lays greater stress on the gratification of male sexual needs and wives' obligation to cater to them.

There exists a bias in favour of male sexual gratification even in contemporary Muslim legal discourse. Saudi mufti Ibn Jibreen's popular fatwa (religious decree) entitled "The Ruling on Either of the Two Spouses Denying the Other their Lawful Rights" is relevant in this connection. What is appreciable is Ibn Jibreen's initial acknowledgment that sexual needs are equally found among both males and females. He eschews the popular belief that women's sexual desires are unmanageable and opines that men generally have a stronger desire for sex than women. What is interesting is the rest of fatwa which looks at the sexual rights of wives as limited and contingent, especially in contrast to the unrestricted right of a husband to have sex with his wife. The phrase employed by Jibreen "whenever he desires it" is of significance here. What is noticeable is the passivity attributed to the wife who must "allow" the husband to have sex rather than being an active participant in it. Ibn Jibreen recognizes that wife too enjoys the right over her husband regarding her sexual gratification though the latter is not obliged to satisfy the former whenever "she" desires it; rather he must have sexual intercourse with her at least once in each third of a year (Ali 2008: 10).

Prophet Mohammad's (peace be upon him) close companion Abu Hurairah is the authority regarding narrations from the Prophet which associate the displeasure of the husband with that of the divine. If a woman spends the night deserting her husband's bed (does not sleep with him), the angels send their curses on her till she comes back (to her husband) (Al Bukhari Book 62). Unlike the dire consequences (the divine wrath) against not pleasing her husband, a sexually dissatisfied wife has been shown few ways to redress despite the fact that men too are bound to keep their wives satisfied. In one case, however, the Prophet is reported to put straight a man who boasted of fasting daily and praying every night. The Prophet asked the man to follow his example and bring moderation to his devotion to Allah. The hadith is important to scholars like al-Ghazali who focus on the words used by the Prophet implying that wives are almost an extension to their husbands' bodies: "Your body has a right over you, your eyes have a right over you and your wife has a right over you" (Al Bukhari Book 62). These words by the Prophet, according to Ghazali, lead to the larger issue of wives' sexual rights over their men. 
It is interesting to study how female sexuality is perceived in some Muslim societies. Contrary to Gulshan is the situation of Naghmana who also suffers the sense of deadly guilt, as she is accused of alluring Haroon by displaying her body. It is worth noticing at this point that despite the intense wrath Hajra, Gulshan and other women have against Haroon, nobody takes Haroon an accomplice with Naghamana in the act of their alleged adultery. Only Sardara, the village milk woman, gives a passing reference to Haroon as she remarks, "I am sure she didn't physically drag him out of his wife's bed. Haroon went to her willingly, didn't he?" (Typhoon 2003: 67.) The entire burden of sin is, therefore, wrongly shifted to Naghmana as her voluptuous, unveiled and attractive body proves to be the cause of upheaval in the entire village. Shahraz's novel reveals that female sexuality is feared among the inhabitants of Chiragpur. Naghmana happens to travel alone to the village. She does not observe purdah(the veil) and so creates stir among the villagers, men and women. Siraj Din, the village elder, is badly offended by the way she carries herself. Her modern and bold appearance elicits anger and disapproval from the moment she enters the village and comes across Siraj Din: "she was a stranger in 'his' village and one who didn't attempt to cover her head in his presence. Siraj Din dismissed her salutation and pointedly ignoring her walked on" (Typhoon 2003: 3). Izugbara (2004) discusses female sexuality in terms of the status it enjoys in the Muslim discourse. For Muslim women, remaining modest is considered a celebrated value. Staying chaste guarantees modesty, and for its preservation, women are expected to avoid publicity and free socializing with men.

From an Islamic perspective, as discussed earlier, women are expected to dress modestly in public. This is because their unveiled and adorned figure may incite lust and become disruptive both morally and socially. Naghmana's modernity alludes to the uncontrolled female sexuality as it is perceived by the villagers in Chiragpur. The village is, therefore, plagued by fitna or chaos. In the light of Islamic scholarship too, Ibn al-A'raabi holds that fitna means a number of things including testing, trial, wealth, children, kufr, differences of opinion among people, and burning with fire.Badran (2009), in this connection, asserts that women are popularly believed to have enormous sexual appetites in the learned Islamic texts. These appetites are far greater than the sexual needs on the part of the males. This reduces women's entire being and their voice to a sexualized entity.

Fatima verbally lashes Naghmana telling her that she is simply a prey to her sexual appetite, “If you were so desperate for a man, why didn't you tell us, for God's sake? We could have married you off" (Typhoon 2003: 54). At this point, one is reminded of Habib Khan in The Holy Woman who uses the same tactics to prevent his daughter(Zari Bano) from marrying Sikander. This tells the readers that women like Naghmana and Zari Bano are hostages to a sense of shame which is unavoidably attached to either their bodies or sexuality. Zari Bano gives up her right to marriage as she cannot take this sense of shame and immodesty which is attributed to her. Similarly, Naghmana is believed to be a whore who succumbs to this sense of shame as Fatima mourns:

You have ruined me, Naghmana! Me - your widowed childless aunt. Have you no shame, no sharm? You slut! I have lost our izzat, our family honour because of you. You have dumped it all away and buried us all in the mud of disgrace (Typhoon 2003: 54).

It is, however, ironic that the same sexuality which is kept concealed among Muslim cultures becomes the cause of public shaming in case something wrong is committed by a woman. The village people are not ready to forgive Naghmana for the alleged adultery that she has committed. Fatima feels doomed as her niece has brought guilt and shame to the family. It can thus be inferred that the sexuality of a woman belongs more to her family than to her individual self.

\section{The Authenticity of the Male Voice}

The rural setting of Chiragpur provides a backdrop to Naghmana and Haroon's situation where a stark difference can be noticed in the authority enjoyed by the male voice, especially when contrasted to the female voice. The village kacheri is a body which is headed by Siraj Din - the elder of the village. Kacheri is an entirely male body which, according to Chaudhary (2013), is a 
battle ground where the sinners are summoned and shamed, while they are watched by the people. Shahraz brings forth the two alleged sinners to the battle ground; what is remarkable is the contrast how a woman is put to shame, while the man still holds his head high. We see Naghmana dressed badly in her aunt's old clothes. Her body is wrapped by a chador(shawl) and "Naghmana's head bowed in shame before the spectators' gaze. She lets her aunt's old muslin shawl slide further down to cover her face to shield her from the hostile gazes" (Typhoon 2003: 158). Sharply contrasted to this is Haroon's indifference to the situation and confidence: "His head held high he strode towards the three chairs on one side of the table. Ignoring everyone, he sat down. He looked straight ahead at the horizon" (Typhoon 2003: 153).

It is Haroon who reveals the reality of his relationship with Naghmana for the first time. Hitherto, we see Naghmana being abused and disgraced by everyone. However, the poor woman never dares to tell that she is Haroon's legal wife. This, in fact, demonstrates the lack of authority in the female voice. It is Haroon who, in the kacheri, gives out that he secretly married Naghmana and then got separated while they were students. This infuses a kind of new life in Naghmana. Her body, in a way, does not belong to her. Until reclaimed by Haroon as his wife, Naghmana's body is the emblem of shame, guilt and sin. She does not have the courage to stand up and speak for herself. Once claimed by Haroon, she regains her lost honour and pride. This reflects the dearth of self-value as well as the inability of the female voice to claim her own identity. A further show of male authority and chauvinism can be seen through Siraj Din who is presiding the kacheri meeting. Siraj Din is determined to restore order in his village at any cost and, therefore, pressurizes the unwilling Haroon to pronounce three verbal divorces to Naghmana in front of the mob. Once Haroon does it, Siraj Din returns Naghmana's lost honour to her by patting on her head: “Miraculously, Siraj Din's hand reached out to her bowed head and fell flat on it. The villagers gasped. The badkismat woman had been re-instated" (Typhoon 2003: 174).

The entire episode is nothing but a demonstration of sheer ignorance of the villagers. The village elders like Siraj Din tend to establish their so-called prestige at the edifice of their women's honour. Naghmana is considered a source of fitna without paying any heed to what actually happened the night Gulshan and Hajra saw her with Haroon. Islam's emphasis on the availability of a stringent proof against zinaor adultery should essentially be brought in at this point. The Qur'an asks for four eyewitnesses in order to prove the offence of zina. These witnesses, as the jurists hold, must be adults, male, Muslim and testify having seen the real and actual act of sexual intercourse. The extent of precision of such testimony can be assessed through various analogies such as the key going into a lock, or a pen dipping into an inkpot.

Siraj Din compels Haroon to verbally divorce Naghmana three times there and then in the kacheri. Haroon unwillingly follows the order and Naghmana gets loose from the bond of marriage. Engineer (2008) discusses the nature of divorce as it is treated in Islam and holds that it may often be used by the dominant party, especially men, in a patriarchal society owing to the fact that it is a contract. Islam discourages divorce and establishes that divorce should be avoided to the maximum possible extent. A reported saying of the Prophet states, "God did not make lawful anything more repugnant to Him than divorce" (Sunan Abu Dawud Book 6). However, divorce is permissible in Islam as marriage has been instituted as a contract. Islam's treatment to divorce is quite unlike what we find in Christianity and Hinduism where marriage is conceived as a sacrament. The concept of marriage naturally entails divorce when it is established as a contract between two parties, i.e. husband and wife. This, in fact, is the virtue attached to marriage by Islam as the total absence of divorce too can be problematic.

Islam strongly recommends reconciliation in case a rift arises between a husband and wife. From this point of view, a hakam (arbitrator) should be there who must appoint an arbiter from each of the two sides (Quran 4: 35). Both the arbiters must probe the actual causes of the dispute between the spouses while trying to find a suitable way for reconciliation. The relatives of the two spouses are indeed best qualified for this as they are believed to have true and comprehensive knowledge of the actual circumstances leading to the rift. 
Islam also discourages three simultaneous divorces. As the Quran (2:229) states, "A divorce may be [revoked] twice, whereupon the marriage must either be resumed in fairness or dissolved in a goodly manner" (trans. Asad 84). This implies that the husband must take final decision after the completion of two divorces and prior to the third divorce within which he may take his wife back. Mahmud bin Labeed reported that the Prophet was once told about a man who gave three divorces to his wife at a time. He, on hearing this, got up enraged and exclaimed, "Are you playing with the Book of the Almighty Allah while I am (still) amongst you?" Seeing the fury of the Prophet, a man got up and said, "Shall I not kill him?" (Sunan al-Nasa'i Book 27).

To conclude, Shahraz's Typhoon opens up possibilities for Pakistani women to show covert resistance to the complex web of social mythologies and cultural norms which feature their lives. There are scarce possibilities of an overt resistance as it has been purposefully made impossible by men or may carry dire consequences for women. Pakistani women, especially those from rural backgrounds, are handicapped and compelled to yield to the male-centered life patterns. They are forced to accept men in the position of central authority who enjoy the privilege of laying out rules of right and wrong in gender relations. This is what appears in Shahraz's Typhoon wherein the polemics surrounding the female body in countryside Pakistan force women to be ashamed of and even fear their own sexuality. The culturally-construed notion of izzat or honour is (mis)appropriated always against the female body while men are generally exempted from it. Womanhood thus becomes a burden for women like Naghmana and Gulshan who confront invariable strife fighting for and reclaiming it, though it is always men who eventually have the power to end up this vicious circle of indignation.

Shahraz's rationale of writing novels like The Holy Woman and Typhoon is to impart a renewed consciousness, especially to women readers, who need to re-evaluate their position in the context of Islam. This explains why her female characters are not only conscious of their bodily manipulation but also put up resistance to such enclosures to the best of their capacity. She is critical of the wholesale import of the Western discourse, especially on hijab and women's rights in Islam, which raises hue and cry against the anarchy of the so-called Islamic fundamentalism.

The destituteness and impoverishment experienced by women like Gulshan or Naghmana act as a springboard for Pakistani readers in general and female readers in particular to decode the religious faith which is manipulated in favour of tradition or tribalism. There exists policing against the feminine, and especially the female body, which ultimately turns into a site where the cultural and normative misogyny is enacted and then legitimized in the garb of a supposedly religion-based patriarchy.

\section{References}

Ali, Kecia. 2008. Sexual Ethics in Islam: Feminist Reflections on Qur'an, Hadith and Jurisprudence. Oxford: Oneworld Publications.

Al-Khattab, Nasiruddin. 2007. Sunan An Nasai : English, Arabic : 6 Volume Set. Riyadh: Maktabah Darussalam.

Anne, Lin. Qaisra Shahraz: 2008. Unveiling Muslim Women. The Jakarta Post. https://www.thejakartapost.com/news/2008/01/31/qaisra-shahraz-unveiling-muslimwomen.html. Retrieved: April 19, 2020.

Asad, Mohammad.1980. The Message of the Qur'an. (Trans.). Gibraltar: Dar Al-Andalus.

Badran, Margot. 2009. Feminism in Islam: Secular and Religious Convergences. Oxford: Oneworld Publications.

Chauhdary, Fariha. 2013. Hiding and Seeking Identity: The Female Figure in the Novels of Pakistani Female Writers in English. (Unpublished doctoral dissertation). UK: University of Huddersfield Repository. http://eprints.hud.ac.uk/ 17563/.Routledge. Retrieved: May 22, 2020.

Cowan, Michael A. 2000. Introduction to Practical Theology. New Orleans: Loyola University. Engineer, Asghar Ali.2008. Rights of Women in Islam. New Delhi: Sterling Publishers Pvt. Ltd. 
Hasan, Md. Mahmudul. 2016. Distinguishing Islam from cultural practices: Conversations with Qaisra Shahraz. Asiatic: IIUM Journal of English Language and Literature . 10 (1): 71-183. https://journals.iium.edu.my/asiatic/index.php/ajell/article/view/751.

Hoff, Angelika. 2011. Qaisra Shahraz's Typhoon: a muslim perspective on adultery. pp. 45-61. In, Abdur Raheem Kidwai\& Mohammad Asim Siddiqui (eds). The Holy and the Unholy: Critical Essays on Qaisra Shahraz's Fiction. New Delhi: Sarup Book Publishers.

Isgandarova, Nazila. 2014. Practical theology and its importance for Islamic theological studies. Ilahiyat Studies. 5 (2): 217-236. https://doi.org/10.12730/13091719.2014.52.109

Ishaque, Nausheen. 2017. Violence ritualized: the chemistry of tradition and religion in Qaisra Shahraz's the Holy Woman. SAGE Open (January-March): 1-8.

Izugbara, Chimaraoke Otutubikey.2004. Patriarchal Ideology and Discourses of Sexuality in Nigeria. Paper presented at the Understanding Human Sexuality Seminar Series 2 African Regional Sexuality Resource Centre ARSRC. 1-34.

Khan, Mohammad Muhsin. 2005. Translation of Sahih Bukhari. International Islamic University. http://www.iium.edu.my/deed/hadith/bukhari/. Retrieved: June 6, 2020.

Kidwai, Abdur Raheem. 2011. Recontextualization of Muslim society and modernity in Qaisra Shahraz's the Holy Woman. pp. 81-105. In, Abdur Raheem Kidwai \&Mohammad Asim Siddiqui (eds).The Holy and the Unholy: Critical Essays on Qaisra Shahraz's Fiction.New Delhi: Sarup Book Publishers.

Leo, Elizabeth Shalala. 2005. Islamic female sexuality and gender in modern feminist interpretation.Islam and Christian-Muslim Relations.16 (2): 129-140

Lindo, Karen. 2013. Interrogating the Place of Lajja (Shame) in contemporary Mauritius. pp. 212228. In, Johnson, Erica L. \& Moran, Patricia. (eds.), The Female Face of Shame. Indiana: Indiana University Press.

Moosa, Ebrahim. 2005. Al-Ghazali and the Poetics of Imagination. USA: University of Carolina Press.

Partial Translation of Sunan Abu Dawud: Book $6 . \quad$ n.d. https://www.iium.edu.my/deed/hadith/abudawood/006_sat.html. Retrieved 7 June, 2020.

Shahraz, Qaisra. 2001.The Holy Woman. Islamabad: Alhamra Publishing.

Shahraz, Qaisra. 2003. Typhoon. Islamabad: Alhamra Publishing.

Siddiqui, Mohammad Asim. 2011. The political or the social? Qaisra Shahraz and the present Pakistani writing in English. pp. 183-204. In, Abdur Raheem Kidwai \& Mohammad Asim Siddiqui (eds.). The Holy and the Unholy: Critical Essays on Qaisra Shahraz's Fiction. New Delhi, India: Sarup Book Publishers.

Siddiqui, Mohammad Iqbal. 2010. The Family Laws of Islam. New Delhi: Adam Publishers and Distributors.

Smith, Gary Kavin. 2008. Academic Writing and Theological Research: A Guide for Students. Johannesburg: South African Theological Seminary Press.

Young, Robert J. C. 2003. Postcolonialism: A Very Short Introduction. Oxford: Oxford University Press. 